\section{JAK inhibitors as promising agents for refractory Takayasu arteritis}

I read with great interest the article 'Successful remission with tofacitinib in a patient with refractory Takayasu arteritis complicated by ulcerative colitis' by Kuwabara et al. ${ }^{1}$ In this article, the authors reported a patient with both Takayasu arteritis (TAK) and ulcerative colitis (UC) who was successfully treated with tofacitinib, an inhibitor of Janus kinase (JAK). The critical message of this report is that, although inhibitors of tumour necrosis factor $\alpha$ and interleukin (IL)- 6 failed to induce remission, symptoms and arterial inflammation on imaging were promptly ameliorated by tofacitinib. ${ }^{1}$ Because our group reported the efficacy of JAK inhibitors on experimental large-vessel vasculitis in mice for the first time, ${ }^{2}$ I would like to comment on this report.

First, UC is not an uncommon complication in TAK, with a complication rate of approximately $6 \% .{ }^{34}$ However, it has been reported that TAK patients with UC have a different genetic background from TAK patients without UC in HLA-B52:01 positivity, and that the age of TAK onset in the former group is younger than that in the latter. ${ }^{4}$ Thus, it may be possible that JAK inhibitors are more likely to be effective in patients with both diseases. It is necessary to test whether JAK inhibitors are efficacious in TAK patients without UC as well.

Second, a genome-wide association study revealed $I L-12 B$ as a susceptibility gene in TAK, and IL-12 plays a critical role in T helper 1 (Th1) differentiation. ${ }^{5}$ In addition, patients with TAK have a higher serum concentration of IL-23 than healthy individuals, and IL-23 promotes IL-17 production by $\mathrm{CD}^{+}{ }^{+} \mathrm{T}$ cells. ${ }^{78}$ Both IL-12 and IL-23 are critically involved in the pathophysiology of TAK and activate JAK2 and Tyk2. ${ }^{9}$ Because tofacitinib primarily inhibits JAK1 and JAK3, baricitinib, an inhibitor of JAK1 and JAK2, may be a better option in some patients.

Third, the authors seem to believe that the efficacy of tofacitinib is mediated by blocking Th1-derived and Th17-derived cytokines. However, JAK inhibitors, including tofacitinib, target not only $\mathrm{CD}^{+}{ }^{+} \mathrm{T}$ cells but also macrophages and natural killer cells, ${ }^{210}$ which have recently emerged as a promising target in TAK. ${ }^{11}$ Because TAK is a multifactorial disease in which many cytokines and cell populations interact with each other in the disease mechanism, multicytokine blockade with JAK inhibitors rather than single cytokine inhibition may be reasonable.

Whether JAK inhibitors can be considered as first-choice immunosuppressive agents added to glucocorticoids (GCs) or even an alternative to GCs for TAK remains unclear. However, although there are some concerns with JAK inhibitors, such as herpes zoster and malignancies, given the significant burden of GCs on patients with TAK, I believe this issue should be discussed in the future.

\section{Ryu Watanabe 우}

Correspondence to Dr Ryu Watanabe, Department of Rheumatology, Osaki Citizen Hospital, Osaki, Japan; doctorwatanaberyu@yahoo.co.jp

Contributors RW is the sole author of this article.

Funding The authors have not declared a specific grant for this research from any funding agency in the public, commercial or not-for-profit sectors.

Competing interests None declared.

Patient and public involvement Patients and/or the public were not involved in the design, or conduct, or reporting, or dissemination plans of this research.

Patient consent for publication Not required.

Provenance and peer review Not commissioned; internally peer reviewed.

(c) Author(s) (or their employer(s)) 2020. No commercial re-use. See rights and permissions. Published by BMJ.

$$
\text { Check for updates }
$$

To cite Watanabe R. Ann Rheum Dis Epub ahead of print: [please include Day Month Year]. doi:10.1136/annrheumdis-2020-217577

Received 10 April 2020

Accepted 15 April 2020

Ann Rheum Dis 2020;0:1. doi:10.1136/annrheumdis-2020-217577

\section{ORCID iD}

Ryu Watanabe http://orcid.org/0000-0002-1089-5296

\section{REFERENCES}

1 Kuwabara S, Tanimura S, Matsumoto S, et al. Successful remission with tofacitinib in a patient with refractory Takayasu arteritis complicated by ulcerative colitis. Ann Rheum Dis 2020. doi:10.1136/annrheumdis-2019-216606

2 Zhang H, Watanabe R, Berry GJ, et al. Inhibition of JAK-STAT signaling suppresses pathogenic immune responses in medium and large vessel vasculitis. Circulation 2018;137:1934-48.

3 Watanabe $\mathrm{R}$, Ishii T, Nakamura K, et al. Ulcerative colitis is not a rare complication of Takayasu arteritis. Mod Rheumatol 2014;24:372-3.

4 Terao C, Matsumura T, Yoshifuji $\mathrm{H}$, et al. Takayasu arteritis and ulcerative colitis: high rate of co-occurrence and genetic overlap. Arthritis Rheumatol 2015;67:2226-32.

5 Terao C, Yoshifuji H, Kimura A, et al. Two susceptibility loci to Takayasu arteritis reveal a synergistic role of the $\| 12 \mathrm{~b}$ and $\mathrm{HLA}-\mathrm{B}$ regions in a Japanese population. Am J Hum Genet 2013;93:289-97.

6 Trinchieri G. Interleukin-12 and the regulation of innate resistance and adaptive immunity. Nat Rev Immunol 2003;3:133-46.

7 Saadoun D, Garrido M, Comarmond C, et al. Th1 and Th17 cytokines drive inflammation in Takayasu arteritis. Arthritis Rheumatol 2015;67:1353-60.

8 Gaffen SL, Jain R, Garg AV, et al. The IL-23-IL-17 immune axis: from mechanisms to therapeutic testing. Nat Rev Immunol 2014;14:585-600.

9 Watford WT, Hissong BD, Bream JH, et al. Signaling by IL-12 and IL-23 and the immunoregulatory roles of STAT4. Immunol Rev 2004;202:139-56.

10 Moodley D, Yoshida H, Mostafavi S, et al. Network pharmacology of JAK inhibitors. Proc Natl Acad Sci U S A 2016;113:9852-7.

11 Terao C, Yoshifuji H, Matsumura T, et al. Genetic determinants and an epistasis of LILRA3 and HLA-B*52 in Takayasu arteritis. Proc Natl Acad Sci U SA 2018;115:13045-50. 